\title{
$6 \mathrm{c} / \mathrm{s}$ spike and wave $の$ Diphenhydramine hydrochloride (DPHm) による賦活
}

\author{
一特に wave and spike phantom (WSP) の性状についてー \\ 岡山大学医学部神経精神医学教室（主任：大月三郎教授）
}

高橋茂

(昭和57年 1 月 27 日受稿）

\begin{abstract}
Key words: 脳波, wave and spike phantom (WSP),
健康成人,

Diphenhydramine hydrochloride (DPHm)
\end{abstract}

\section{はじめに}

1950年, Walter ${ }^{11}$ は持続が短く，振幅の低い $6 \mathrm{c} / \mathrm{s}$ spike and waveが形態上, 小発作波型に 似ているところからっこれを phantom petit mal と呼んだ. 次いで Marshall2)が, この波型を wave and spike phantom と名付け，一般的に はWSPとして知られてきた（以後便宜上この 波型をWSP として記述する.）このWSPは， 型態上明らかな表出であるが、これに対応する

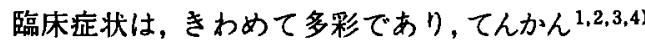
精神疾患4,5,6,7,8)行動異常9,10,11) 自律神経症状 $4,12,13,14)$ などとの相関が報告されている．また何らの認 むべき臨床症状のない健康对象群にも，稀にWSPが認められるという報告もある3 ${ }^{3,15,16,17) . こ ~}$ うした事情から，WSPと特定の臨床症状との特 異的对応を疑j報告も多い16,17，18). 棘波成分を有 し，その他のてんかん性異常波之類似の形態を 示すにかかわらず，この波型が,なんらかの精 神神経学的表出の基盤を成しているのかどうか, いまだに必ずしも明確な答えはえられていない。 したがってWSP が, 臨床診断の明らかなてん かん患者に認められた場合はそれとして，臨床 診断の明らかでない非てんかん者に認められた 場合の当惑と混乱は，なお存在していると言わ さるをえない，またWSP波型については，6-14 c/s posititive spikesとの関連もこれまでに論
じられてきた18.19.20.21)すなわち両者が同一記録 中によくみられること，各々の波型に対応する かにみえる臨床症状に共通性があることなどか ら，両者を同一性状のものとする意見もある ${ }^{19,20)}$. また両者は Diphenhydramine hydrochloride （以下DPHm と略す）の静脈内注射により，か なり特異的に誘発されることも指摘されてき た ${ }^{14,16,17,22,23)}$.これまでの報告の多くは，もと より患者群を対象としたものであった。しかし， すでに述べたごとく，WSPは健康成人に稀では あるが認められる以上，この点の検討が著者ら の大いなる関心事であった．今回，著者らは， 8 年余にわたり，ある公務に従事する健康成人 男子を対象とする脳波検査の依頼を受け，その 記録に際して,ルーチン脳波検查の後, 脳波賦 活の一法として, DPHm 賦活検查を施行する機 会に恵まれた：これらの結果は，年次的にすで に発表し $24,25,26,27,28)$, 中間報告としてHosokawa et alが一部まとめを行なった ${ }^{17)}$ 。こうした健康 成人男子を对象とした脳波記録に際し，われわ れのように DPHm 賦活を多数に行なった報告 は，全くない，さらにこれらの对象者の中から， DPHmによって誘発されたWSP 陽性例に，け いれん誘発作用を有するBemegride（以下 Bg と略す）賦活を同時に施行しえた。そしてさら に，逆の順序で，すなわち $\mathrm{Bg}$ 賦活を先に行な い，その中で，てんかん性異常波の出現した 
Bg 賦活陽性者に, DPHm 賦活 を行なうことによって、けいれ ん閾値に関する比較検討も行な

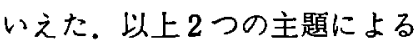
検討は，いまだ十分明らかでな いWSPの性状に関して，ある寄 与をなし，臨床方面に与える資 料としても貴重であると思われ るのでここに報告する。

$6 c / s$ spike and wave一いわゆ

\section{るWSP の定義}

そも无 phantom spike and wave という名称は，小発作と 对比されたもので, miniature petit mal dischargeとも呼ばれ ている13)．しかし報告者によっ て, この波型の周波数, 振幅, 分布に種々の相違が認められる。 周波数に関しては低い周波数の $4 \mathrm{c} / \mathrm{s}^{3,13)}$ からとするものもある

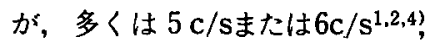
特に $6 \mathrm{c} / \mathrm{s}$ に特徵を求めるもの が多い，年令による周波数の変 動を認めるものもある3.13),田 中によると粮周波数は $5 \mathrm{c} / \mathrm{s}$ から $7 \mathrm{c} / \mathrm{s}$ の範囲で，中でも $6 \mathrm{c} / \mathrm{s}$ が最も多く, 次いで $5 \mathrm{c} /$ $\mathrm{s}, 5.5 \mathrm{c} / \mathrm{s}, 7 \mathrm{c} / \mathrm{s}$ となってい る.しかし同一人の記録中に 単一の周波数でなく，他の周波 数を併有する場合もあり，周波 数の多少の差異に意義を見出す ことはできないとしているもの もある211. 振幅についても， $25 \mu \mathrm{v}$ から $30 \mu \mathrm{v}$ 以下とするも $\sigma^{2.19)}$ ，50 $\mu \mathrm{v}$ 以下とするもの7),

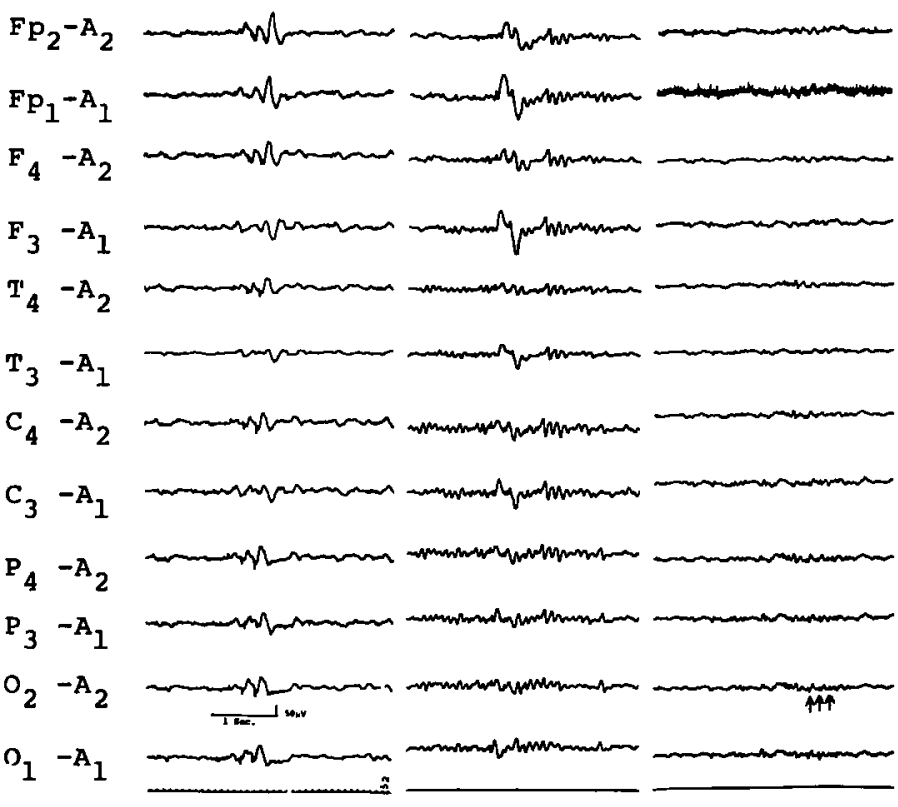

図1-A 単極誘導での $6 \mathrm{c} / \mathrm{s}$ spike and wave (WSP), 矢印は小棘波

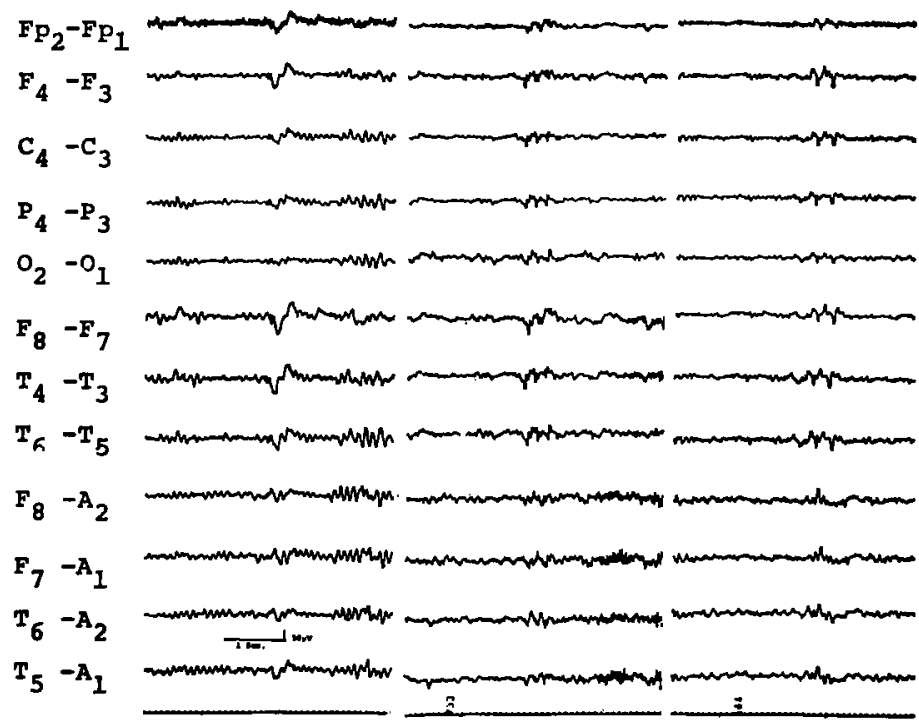

図1-B comparison linkage (Marshall, C.) に よる $6 \mathrm{c} / \mathrm{s}$ spike and wave (WSP)

での文献を絵合すれば，䊂波成分が小形であ ること，したがって，一応 $25 \mu \mathrm{v}$ から $30 \mu \mathrm{v}$ 以下のものを指すと言ってよい．分布について は，多くの報告者が両側同期性を強調 してい $3^{13,16,18,21)}$. しかし，出現部位の優位差を後頭部 
に求めるものもある ${ }^{1,18)}$. 一方, 前頭優位のもの もあることも指摘されている13)。こうてみる と, 周波数, 振幅, 分布いずれもWSP につい ては一般に莫然と容認されているにすぎないと もいえる。そこで今回 WSP と判定したサンプ ルを困 1 に示し，今回のWSP の定義について 述べたい，図1Aは単極導出，図1BはMarshall の推獎する comparison linkage ${ }^{21}$ にっって得ら れたものである．すなわち著者は，今回周波数 を $5 \mathrm{c} / \mathrm{s}$ から $6 \mathrm{c} / \mathrm{s}$ 前後, 梀波と徐波の振幅は低 く，特に棘波は $25 \mu \mathrm{v}$ から $30 \mu \mathrm{v}$ 以下のものをWSP とした。従って棘波成分の明瞭な，いわゆる atypical spike and wave complexはたとえ $6 \mathrm{c} / \mathrm{s}$ であってもWSPとしていないことを特に 付記しておきたい.

\section{対象と記録方法}

今回の研究対象は，なんらの精神神経症状を 持たない健康成人男子787名(18才から40才, 平 均24.4才)である。ある公務に従事するに際し て，脳波検查が必要と考之られ，岡山大学神経 精神科に依頼されたものである．脳波検查に際 しては，各被検者に検查内容の説明を十分行な った上で検查を施行した，脳波検查に先立ち， 既往歴すなわち頭部外傷, 熱性けいれん, 脳症, 精神神経疾患の有無の他, 向精神薬の服用の有 無などを調查した．また神経症傾向のチェック のため Cornell Medical Index (CMI) テストを 施行した。脳波記録は，三栄測器製 IA-74 と， IA 12-14Cの13チャンネルの脳波計を使用した。 電極の位置は国際的な Ten-Twenty system を 採用し，耳染を不関電極とする単極導出と頭皮 上の配置電極間を結ぶ双極導出を用い，モンタ 一ジュは岡山大学神経精神科脳波室で定められ た方法によった，对象者全員に，通常施行され るごとく，安静閉眼時記録，ストロボ閉光によ る間歇性光刺激， 3 分間の過呼吸賦活を行なっ た。このルーチン脳波検查の後, DPHm賦活 を行なった。この際 DPHm 用量の差による賦 活率をまず検討した，DPHmを用いた对象は， この脳波検查が年次的に行なわれたため，主と して昭和 49年から昭和56年に至る470名(18才か ら33才，平均23.6才) である。DPHm投与量は
研究方向にそって，年次的に4段階に分け， 0.5 $\mathrm{mg} / \mathrm{kg}, 1.0 \mathrm{mg} / \mathrm{kg}, 1.5 \mathrm{mg} / \mathrm{kg}, 2.0 \mathrm{mg} / \mathrm{kg}$ で 行なった．各投与量の对象者数は，それぞれ52 名，72名，189名，157名であった．各投与量に より对象者数が異なるのは，本検查が長年にわ たってなされたもので，各年により被検者数に 変動があったためである，DPHmは1.5\%水溶 液を用い，30秒間に $1 \mathrm{cc}(15 \mathrm{mg})$ の速度で肘窩 部の静脈より静注した。また DPHm 静注後の 脳波記録は Marshall') $の$ 言 j comparison linkage（図 2 ）を採用し，単極導出も合わせ20分

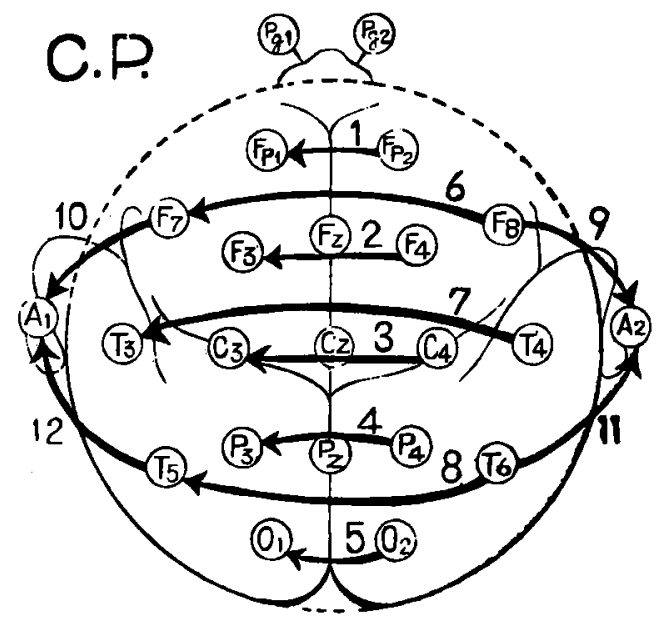

目 2. Marshall, C. (1955) の推奖する comparison linkage (C.P.)

から 30 分間記録した，第 2 の研究は，昭和53年 から昭和54年までの対象者95名（20才から30才， 平均 24.2 才）に $1.5 \mathrm{mg} / \mathrm{kg}$ を投与し，その結果 出現したWSP 陽性例に， Bg 賦活を行ない比較 検討したものである。つまり $\mathrm{Bg}$ によって通常 検討される、けいれん閾值との関連を検討する ことにした．第 3 の研究は，これらとは別の对 象119名(20才から40才, 平均24.4才) に对し, まず $\mathrm{Bg}$ 賦活を施行し、これにより棘波を含 む突発波が出現した例に，DPHm賦活を行ない，

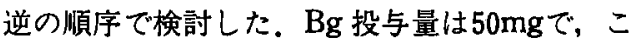
れは大能31)の言う臨床上低阔值群を検出すると される比較的少量を用いた。これを20秒に $1 \mathrm{cc}$ （5 mg）の速度で静注した。また $\mathrm{Bg}$ 投与関始 時に同時に脳波記録を開始し，もし棘波を含む 突発波が出現すれば，その時点で静注を中止す ることにした. $50 \mathrm{mg}$ 全量を投与した者につい 
ては，静注終了後 4 分から 5 分間記録を続行し， 棘波を含む突発波の出現を観察した。 $\mathrm{Bg}$ 投与 時の脳波記録は単極導出を用いた。

\section{結果}

I．ルーチン脳波 (DPHm 賦活前)における 出現率

ルーチン脳波検査において出現したWSP の 頻度は，全対象者787名中 8 名(1.02\%)であった。 これらはいずれも記録中自然睡眠がみられ，WSP は入眠期に認められた．全例に必ずしも自然 睡眠がみられたわけではない，ルーチン脳波記 録中に，過呼吸賦活，光刺激が行なわれている が,これらの賦活によってWSP が出現した例 は無かった。

II. DPHm 投与によるWSP 賦活率

DPHm の用量別によるWSP賦活率を表 1 に に示した，WSP 賦活率は，DPHm $0.5 \mathrm{mg} / \mathrm{kg}$, $1.0 \mathrm{mg} / \mathrm{kg}, 1.5 \mathrm{mg} / \mathrm{kg}, 2.0 \mathrm{mg} / \mathrm{kg} の 4$ 段階別 投与量の範囲内خ゙は, 合計 470名中77名, 平均 16.4\%であった。また,この範囲内では, DPHm の各投与量に対する用量依存性は，統計的にも 有意差を認めなかった。この結果，DPHm賦活 前の WSP 出現率1.0\%に比へ， DPHm 静注後 のWSP 出現率16.4\%は有意の增加を示したと 言える。また DPHm のこの投与量範囲内では, 重篤な副作用は認められなかった。

III. DPHm 賦活前の脳波と WSP

DPHm 賦活の对象となった470名について， 賦活前脳波を，DPHmによってWSP の出現し た群と，WSPの出現しなかった群とで比較した。 比較項目は, $\alpha$ 波出現率, $\theta$ 波の混入の程度, Runs of $\theta$ の出現, 過呼吸による build upである.こ れらの判定は，すべて視察によった。その結果， いずれの項目においても有意の差は認められな かった。これを表 2 に示した。DPHm投与後の 脳波パターンは，ほとんど例外なく大部分の者 が，低電位の $\alpha$ 波抑制パターン，または軽睡眠 初期に近いパターンを示した。

V. 既往歴とWSP との関連

对象者は上記のIII と同じく，470名について検 討した，頭部外傷，熱性けいれん，脳症，精神 神経疾患の有無を調査した。ただし，項目別に
表 1 ，健康成人における Diphenhydramine hydroloride (DPHm) 投与量と WSP 出現頻度

\begin{tabular}{|c|c|c|c|}
\hline DPHm投与㣎 $(\mathrm{mg} / \mathrm{kg})$ & 対 象 & $\begin{array}{l}\text { WS P } \\
\text { 出垷者数 }\end{array}$ & 出晛頻度 \\
\hline \multicolumn{4}{|l|}{ (DPHm 投与前） } \\
\hline 0 & 787 & 8 & 1.0 \\
\hline \multicolumn{4}{|l|}{ (DPHm 投与偻) } \\
\hline 0.5 & 52 & 8 & 15.4 \\
\hline 1.0 & 72 & 15 & 20.8 \\
\hline 1.5 & 189 & 23 & 12.2 \\
\hline 2.0 & 157 & 31 & 19.7 \\
\hline 計 & 470 & 77 & 16.4 \\
\hline
\end{tabular}

表 2. DPHm 賦活前脳波と DPHm によるWSP と の相関 (对象：DPHm 賦活の対象となった 470名)

\begin{tabular}{|c|c|c|}
\hline DPHm职活前 & WSP (-) : 393 名 & WSP (t): 77 名 \\
\hline $\begin{array}{l}\alpha \text { index } \\
\text { Dominant } \\
\text { Subdominant } \\
\text { Rare }\end{array}$ & $\begin{aligned} 271 & (69.08) \\
80 & (20.48) \\
42 & (10.78)\end{aligned}$ & $\begin{array}{ll}52 & (67.58) \\
15 & (19.58) \\
10 & (13.08)\end{array}$ \\
\hline $\begin{array}{l}\theta \text { wave } \\
\text { Excess } \\
\text { Moderate } \\
\text { Rare }\end{array}$ & $\begin{aligned} 6 & (1.58) \\
75 & (19.18) \\
312 & (79.48)\end{aligned}$ & $\begin{array}{rr}1 & (1.38) \\
22 & (28.68) \\
54 & (70.18)\end{array}$ \\
\hline Runs of $\theta$ & $48(12.28)$ & $10(13.08)$ \\
\hline H.V. build up & $23(5.98)$ & $5(6.58)$ \\
\hline
\end{tabular}

表 3 、既往歴とDPHmによるWSP (対象：DPHm賦活の対象となった470名)

\begin{tabular}{|c|c|c|c|}
\hline & & 既往歴あり & 既往歴なし \\
\hline 総 & 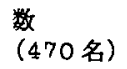 & 112 名 & 358 名 \\
\hline & $\begin{array}{l}\text { P 陽性者 } \\
(77 \text { 名) }\end{array}$ & $\begin{array}{l}22 / 112 \\
(19.68)\end{array}$ & $\begin{array}{r}55 / 358 \\
(15.48)\end{array}$ \\
\hline
\end{tabular}

表 4. CMI 結果と DPHmによるWSP （对象：無作為に選択された279名）

\begin{tabular}{|c|c|c|c|c|c|}
\hline & I 型 & ㅍ & III 型 & IV & 型 \\
\hline $\begin{array}{l}\text { WSP践性者 } \\
\qquad(76 \text { 名) }\end{array}$ & $\begin{array}{c}62 \\
(81.68)\end{array}$ & $(15.88)$ & $\left(\begin{array}{l}2 \\
2.68)\end{array}\right.$ & & $\begin{array}{l}0 \\
081\end{array}$ \\
\hline $\begin{array}{l}\text { WSP秐性者 } \\
\text { (203名) }\end{array}$ & $\begin{array}{l}115 \\
(76.48)\end{array}$ & $\begin{array}{c}40 \\
(19.78)\end{array}$ & $\begin{array}{l}8 \\
(3.98)\end{array}$ & 1 & $\begin{array}{l}0 \\
08)\end{array}$ \\
\hline
\end{tabular}

検討せず，そのうちのいずれか 1 項目以上ある ものを既往歴ありの群とした．その結果，既往 歴の有無と WSP 倵活陽性例，あるいは陰性例 との間に有意の相間は認められなかった。これ 
を表 3 に示した.

V. CMI とWSP との関連

この検討の対象は，DPHm 賦活の对象となっ た470名のうち，無作為に選択された279名であ った。いずれの CMIの神経症傾向の段階におい ても，WSP賦活陽性群と陰性群との間に有意の 違いを認めたものは無かった.これを表 4 に示 した。

IV. 同一人に对する DPHm 賦活と Bg 賦活 比較模討

次に第 2 の研究，すなわち DPHm 賦活によ $\eta$ WSP の出現した例に，Bg賦活を行なった結 果を示す。ここでは，用量別で検討した対象者 のうち, DPHm $1.5 \mathrm{mg} / \mathrm{kg}$ で賦活した95名を对 象者とした。そのうち WSP陽性例は14名(14.7 \%)であった。これら14名に日をあらためてBg 賦活を行ない，その結果 6 名 $(42.9 \%)$ に棘波 を含む突発波を認めた。 これを目 3 上段に示した。 また同一人における両賦活による波型を比較 し，代表的なものを図4A，B，Cに示した，図の 左側に，DPHm 賦活によるWSP，右側に Bg
賦活による棘波を含む突発波を示した. Bg 賦 活による突発波は，6名ともに主として，いわ ゆる atypical spike and wave complexと言わ れている波型であった。しかも脳波図で明らか なようにこれらの梀波を含む突発波の周波数 は, $6 \mathrm{c} / \mathrm{s}$ 前後で, 棘波の振幅は, 著者の規定し たWSP 波型に比べ大きく，あたかもWSP 波 型が增強されたかのような形態をとることが認 められた，次に第 3 の研究は，上記と逆の順㢁 によるものであった.すなわち，119名に对して， ルーチン脳波検查後, DPHmではなく, まず $\mathrm{Bg}$ 賦活を行なった。この結果, 棘波を含む突発波 は14 名(11.8\%)に認められた。

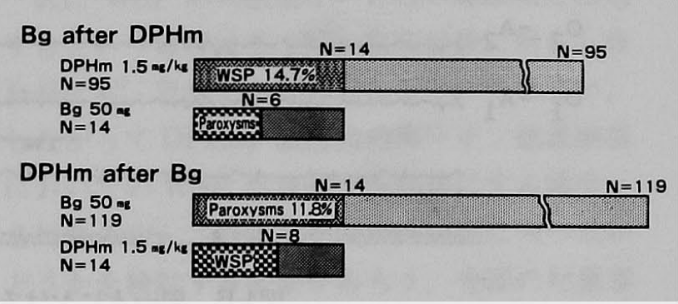

図 3 ．同一人におけるDPHm賦活とBg賦活

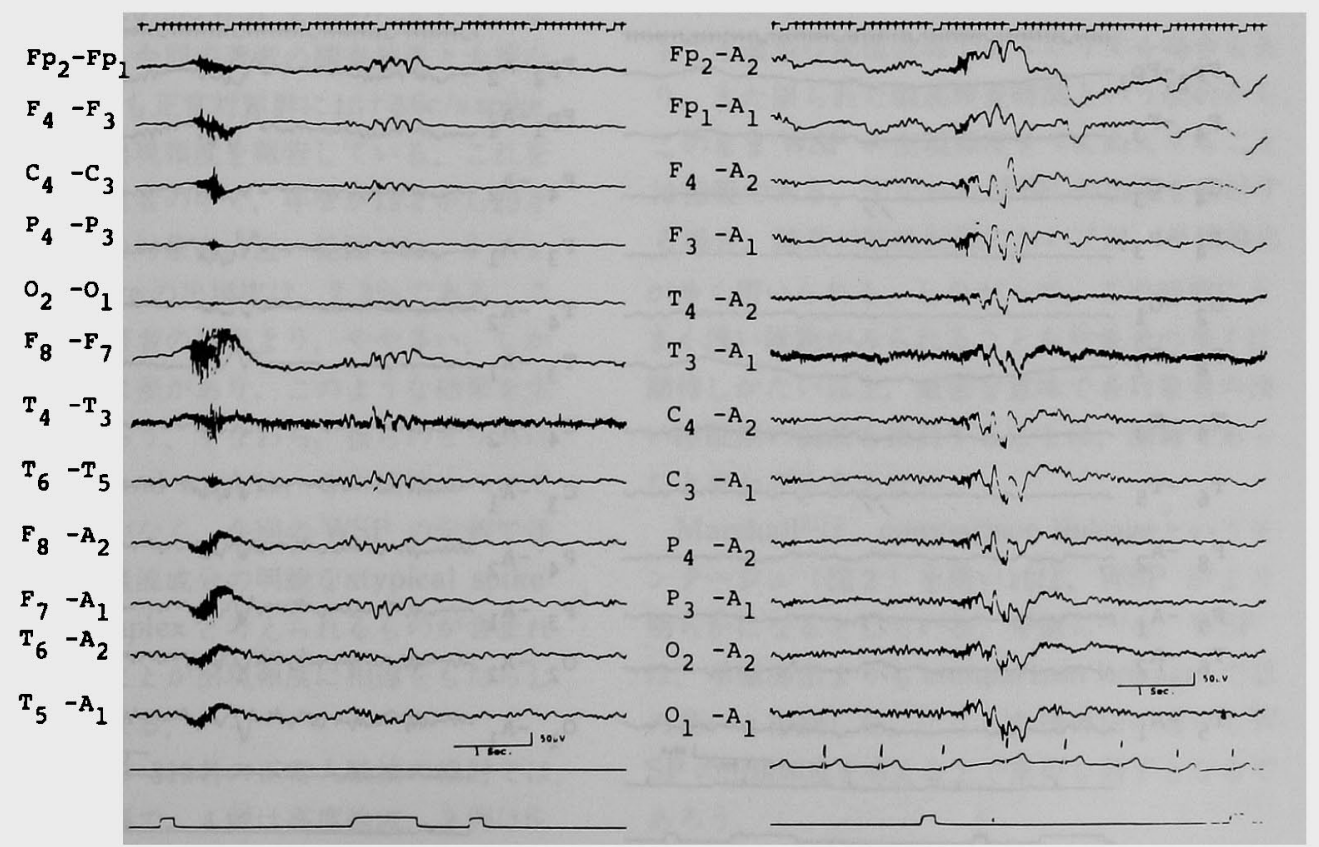

図4-A 同一Aにおける DPHm，Bg 賦活各々の波型 左：DPHm (矢印は小䊂波) 右: Bg 


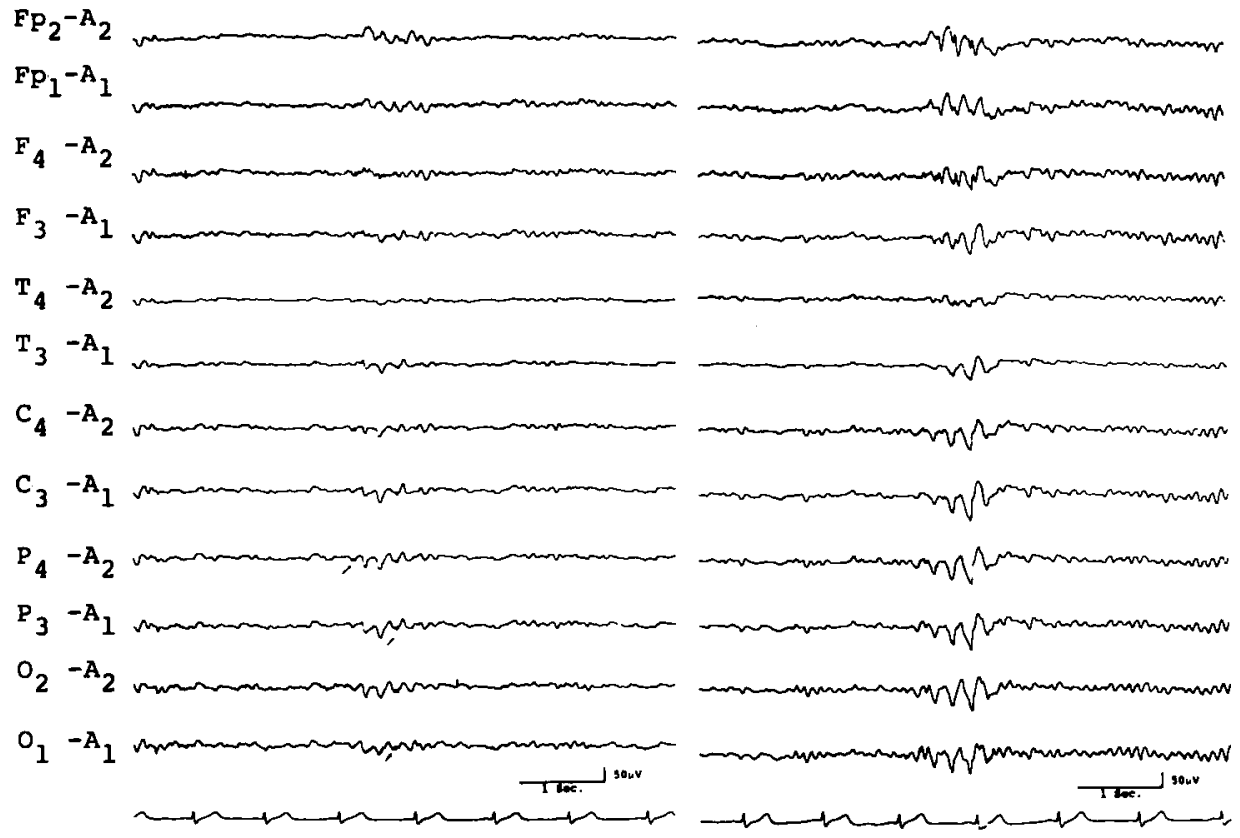

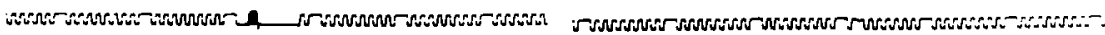

図4-B 同一人における DPHm，Bg 賦活各々の波型 左: DPHm

右: $\mathrm{Bg}$

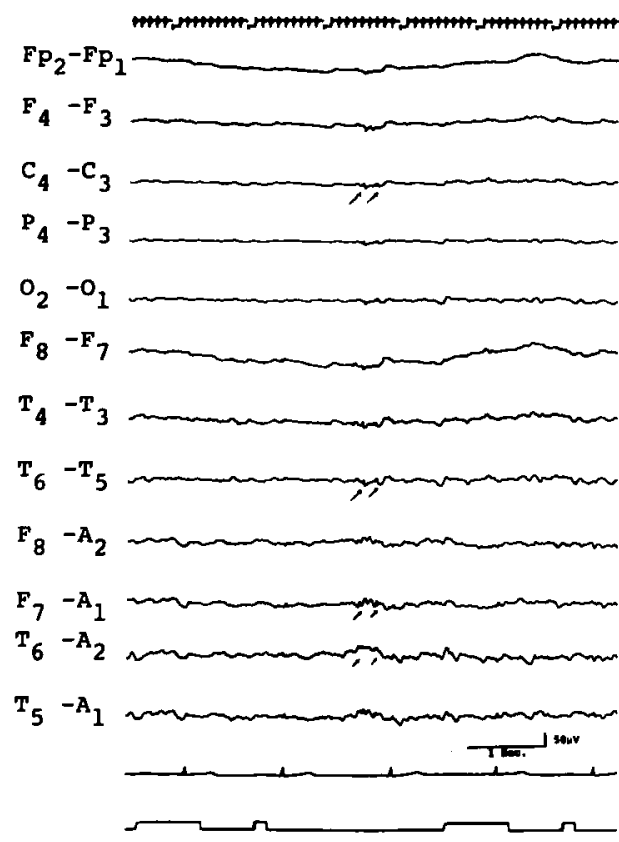

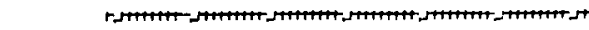

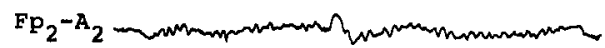

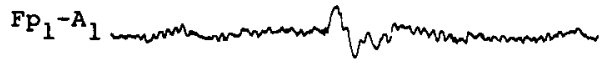
$F_{4}-A_{2}$ -

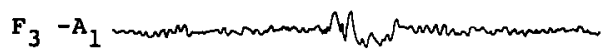
$T_{4}-A_{2}$ $T_{3}-A_{1}$

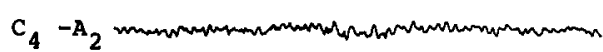

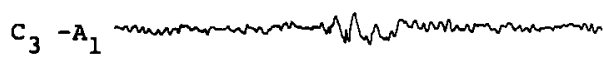

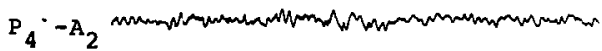

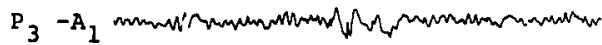

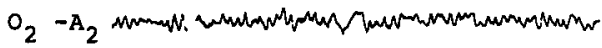

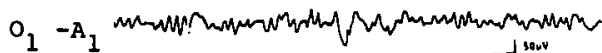

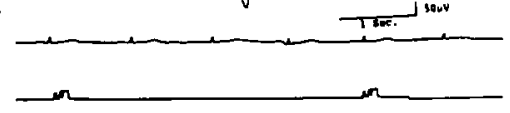

図4-C 同一人における DPHm，Bg 䟼活各々の波型 左: DPHm 右: $\mathrm{Bg}$ 
すなわち atypical spike and wave complex 5 名, WSP 8 名, $6-14 \mathrm{c} / \mathrm{s}$ positive spikes 2 名で,このうち 1 名は atypical spike and wave が併存していた。これらの者に DPHm 賦活を 行なった結果, 8 名 $(57.1 \%)$ に棘波を含む突発 波がみられた。この8名の棘波を含む突発波は, いずれもWSP 波型であった。また,このうち 2 名には 6-14c/s positive spikes が併存してい た.これを図 3 下段に示した。

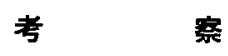

以下，項目別に考察をすすめたい。

1. DPHm 賦活前の WSP 出現頻度

今回の研究は, 特に DPHm賦活によるWSP 出現頻度，WSPの性状に焦点をあてたものであ る。これらの検討に入る前に，まず何よりも一 般の生理的条件下において，すなわちDPHm賦 活前に，はたしてどの程度WSP の出現がみら れたか，あるいは，これまでの諸家の報告は， どうであったかを問題にしたい.

Tharp らは16)，今回の対象群に類似した17才 から28才, 平均21.7才の健康成人男子 195名を 調査し，その1.5\%にWSPを認めたという。こ れは, くしくも今回の著者の調査結果と大差な い. Gibbsら 32 も正常対照群における6c/s spike and wave の出現頻度を報告している。これを みると，全対象者の中で，年令が15才から29才 という, 著者の対象者に近い範囲では, $6 \mathrm{c} / \mathrm{s}$ spike and waveの出現率は，2.3\%である。こ の出現率は, 著者の結果より,やや多い。しか し波型の認定に差があり，このような結果を生 んだものであろう。すなわち，彼らのとりあげ た $6 \mathrm{c} / \mathrm{s}$ spike and waveは, その振幅について の詳しい規定がなく，今回のWSP の定義で述 べたように，棘波成分の明瞭なatypical spike and wave complex と考えられるものが含まれ ている。このことが出現頻度に相違をもたらよ た一因と思われる。

さて越野15)の319名の正常人脳波の検討では, 異常脳波は 8 例で，4例は高度徐波，2 例は6$14 \mathrm{c} / \mathrm{s}$ positive spikes, 1 例に $5 \mathrm{c} / \mathrm{s}$ spike and wave complex, 1 例に phantom spike and wave complex を認めている。したがってspike and wave complexは，2例にすぎない。しか も，この 2 例は，いずれも19才と21才の女子で あった。 Gibbs ら ${ }^{13)}$ も， 6c/s spike and wave

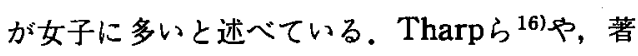
者の結果は，男子のみを対象としたものなので, こうした発作波の出現を問題にする場合には， 性別の考虑も必要となるであろう。

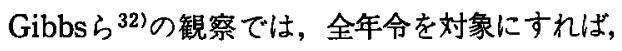
彼らのいう $6 \mathrm{c} / \mathrm{s}$ spike and waveの出現頻度は， $0.8 \%$ となり，15才から29才での出現頻度 $2.3 \%$ に比へ低くなる．したがって対象者の年令は WSPの出現頻度に影響を与える大きな因子と考 えられる。

次にWSP が入眠期ないし浅い睡眠期に出現 するという報告は多く ${ }^{2,3)}$, 臨床経験に照らし合 わせても，日常よく認められるといってよい． したがって DPHm 賦活前のルーチン脳波検查 においてのWSP 出現頻度を問題にする場合, 各对象者が，このような浅い睡眠期に入ったか どうかを検討する必要があろう，今回の対象者 において，少なからざる者が，このような浅い 睡眠期を示した。しかし，たまたま浅い睡眠が みられた時期のモンタージュが, WSP をみる 上で不適当な双極誘導であったりする場合もあ ク，また限られた脳波検査時間という制約から， このままWSP の出現頻度をうんぬんすること は困難である。すなわちWSP の出現を検討す る場合，通常の脳波記録においては，単極導出 が多く用いられる。したがって，この時期にう まく浅い睡眠がみられることを对象者の多くに 期待しがたい以上，㛜密な意味で各对象者の浅 い睡眠期の脳波を検討することは，困難であっ たと言わざるをえない。

Marshall2)は, comparison linkageというモ ンタージュ（図2）を用いれば,WSP がより 明らかになるとしている。平田ら 24)も，WSP は，単極導出よりも comparison linkage で認 め易いと指摘した。こうした誘導法の違いもWSPの出現頻度を考之る上で重要な因子となるで あろう。

田中は30)，臨床を中心として，これまでの広 義 $6 \mathrm{c} / \mathrm{s}$ spike and wave を詳細に検討している. 彼は，その展望において，諸家のデー夕を分析 
し, 出現頻度にかなりの幅がみられるのは, ま ず研究者による周波数や振幅などの判定基準に 由来するものであるという。 また，対象並ひに 記録条件（睡眠，その他の賦活）の違いによる 場合もあり，これらをすへて考㦄した上で，こ の波形の出現頻度を $1 \%$ 内外としている，以上， これまでに述へた諸点を考虑して, 健康対象群 におけるWSP 出現頻度は，WSP の定義，对象 群の性別, 年令, 導出法, その他によって, そ れぞれ異なった結果は得られるものの，一応の 出現率を $1 \%$ 内外と結論してもいいのではない かと思われる。

\section{DPHm 賦活}

DPHm は臨床脳波検查において，これまで比 較的多く賦活薬として使用されてきた。この項 では，本戍の中枢神経系に对する詳細な作用機 序は，さておいて，DPHm 賦活による腷波変化， とりわけ発作波の誘発について検討したい，D$\mathrm{PHm}$ が $1 \mathrm{mg} / \mathrm{kg}$ から $1.5 \mathrm{mg} / \mathrm{kg}$ の投与量で, 脳波上 6-14 c/s positive spikesまたはより狭義 のWSP を特異的に誘発することは，今や一般 によく知られる事実となっている14,16,17,22,23). また, より棘波成分の明瞭なatypical spike and wave complex ${ }^{33,34)}$ その他のfocal spike ${ }^{33,35) な ~}$ どの出現をみたという報告もある。ざらにこう した脳波上の異常にとどまらず，場合によって は，臨床発作の誘発をみたという報告もある ${ }^{35,36)}$. ところが, てんかん群の DPHm 賦活に对する, このような賦活効果に対して, 正常小児群 ${ }^{33)}$, 正常成人对照群 23.35$) の \mathrm{DPHm}$ 賦活では異常波 の誘発を認めなかったという報告が多い。しか し一方, comparison linkage を用いたTharp $ら^{16)}$ は, 平均年令21.7才の 195 人の健康成人の 34例にDPHm 投与総量50mg で賦活を行ない, そのうち10例 $(29 \%)$ に, WSPの誘発を認めて いる. 著者も Tharpにならい, 今回comparison linkage を用いた。その結果, 投与量0.5 $\mathrm{mg} / \mathrm{kg}$ か $2.0 \mathrm{mg} / \mathrm{kg}$ の範囲内では, Tharpら の結果ほど多くはないが, 平均 $16.4 \%$ WSP を認めた。これは DPHm 賦活前に比へ有意に 増加したと言える。

さて一般に薬物倵活について検討する場合は， まず薬物の使用量，賦活の施行方法が問題とな
る。たとえば Bg 賦活においても，投与量の增 加によって，また投与速度の如何によっては， 正常者といえども，全汎性のspike and wave complex が出現し，やがて全身けいれんに移行 することが知られている. DPHm賦活において も，投与量によっては，小児にけいれんをおこ させることが知られている37).この点, 今回の 著者の研究でも, DPHm の投与量, 投与速度が 問題になる。まず，投与量は， $2.0 \mathrm{mg} / \mathrm{kg}$ まで であり, 他の研究者の場合と, さして変わりは ない，すなわち，体重 $\mathrm{kg}$ あたりの投与量，投 与総量においても，類似した量である。しかも， 著者は用量において，段階別に検討を行なうこ とができた。すなわち $0.5 \mathrm{mg} / \mathrm{kg}, 1.0 \mathrm{mg} / \mathrm{kg}$, $1.5 \mathrm{mg} / \mathrm{kg}, 2.0 \mathrm{mg} / \mathrm{kg}$ の 4 段階別投与である. その結果, WSP誘発率に, 各段階別で有意差を 認めず，少なくとも著者の DPHm 使用量の範 囲内では，用量依存性はなかったといってょい。 次に投与速度はどうであろうか. Shimodaら ${ }^{23)}$ や小泉 ${ }^{22}$ は, $30 \mathrm{mg}$ を 1 分間で静注する方法を とっている．著者も同様の方法をとったもので あり，この点，一般に準じたといえる．以上を 小括すれば, DPHm0.5mg/ $\mathrm{kg}$ から $2.0 \mathrm{mg} / \mathrm{kg}$ の投与量の範囲内では，健康成人において，用 量依存性はなかった。したがって一面では，WSP 誘発に对する闌值を設定することはできなか ったということになる。

次に薬物賦活について問題となるのは，当該 薬物の持つ, 特異的な薬理作用である. DPHm は抗七スタミン郕の一種である。抗七スタミン 片の中枢神経系への作用は，本質的には抑制が 主であるという報告 ${ }^{38,399}$ もあるが，一般的には， 興奮と抑制の 2 作用を示すと言われている40). DPHm は, その賦活時に, 脳波上生理的に認め られる入眠期同様の変化をもたらすことから， 一種の睡眠賦活法として取り扱われてきた23,33,34) しかし一般の臨床脳波検查上，入眠期脳波を示 すものは意外に多い。生理的入眠期と,DPHm 賦活時の脳波パターンに類似はみられるものの, 一般に前者において，WSPの出現頻度は決して 多くはない，先に述へたごとく健康对象者の 1 \%内外に認められたにすぎない。これに比べD. PHm 賦活時におけるWSP出現頻度の有意の增 
加は，単純に DPHm が軽睡眠類似の状態をも たらしたためとは言いがたく，DPHmの薬理作 用である中枢神経系への抑制作用の結果と結論 してしまうことにもまた無理があると考えられ る.大田原 ${ }^{411}$ も，自然睡眠によって発作波が誘 発されなかった患児の場合，DPHm賦活が有勃 な場合があるといい，その機序は睡眠誘起のみ にあるのではなく，DPHm の薬理作用を考虑す べきだと指摘している.これらからすると DPHm のWSP誘発に関する効果は，睡眠賦活によるも のとか，中枢神経系に对する抑制の結果と考 えるより，むしろ一方では刺激，あるいは興䶊 効果によるものも考えねばならないであろう。 したがって今回の健康成人における $16.4 \%$ とい う賦活率を合わせると，DPHm を積極的賦活剂 "active activator"として位置づけるとかで きるのではなかろうか.このように DPHm が active activator としての性質を有するらしい ことは，Bg賦活と同様の一面を持つものとして 興味深い。すなわち、DPHm賦活によってWSP が誘発されたことを $\mathrm{Bg}$ 賦活によって突発波が 出現した場合と同様に，健康対象者の背後に素 因性基盤の存在を推定してみることができるか らである。著者らの用いた DPHm 賦活量内で は，用量依存性もなく，そこに闻值のようなも のを設定することはできなかった.しかしpassive でなく, activeな activator としての性質を有す るものと推定される以上，たと之间值の設定が 困難であっても，素因性基盤が否定されること にはならないであろう，Bgは確かに用量によっ ては，健康正常者にも，けいれんをもたらすこ とができる．しかし Bg 50mg 程度を用いて，突 発性波が出現した場合，その对象者は突発性異 常波に関して低間值者であるといってよいこと からすれば，DPHmの適当量によって出現する 類似の突発性波, この際はWSP であるが,こ うした波型の出現者の背景に, 上記のような素 因性基盤の存在を想定しても無理はなかろう。

3.WSP 陽性者の背景について

精神科息者を对象に含む越野ら ${ }^{42}$, Small ${ }^{43}$ も， 紷合病院における患者を对象にしたThomasら ${ }^{18}$ ) Hughesら 44)によっても，賦活威を用いていない ルーチン脳波検查において $6 \mathrm{c} / \mathrm{s}$ spike and wave
またはWSP を示すものは，すでに脳波上，そ の他の異常を併有するものが多いという. 今回 は, DPHm 賦活によるWSP賦活率の検討を行 なったものであるが, DPHm賦活によってWSP の出現した对象者の賦活前脳波はどうであった ろうか.この点においては, WSP陽性例と陰性 例の間における, 賦活前の, いわゆる背景脳波 においては，両群の間に有意の差を見出すこと はできなかった。

次に神経心理学テストなどを用いた对象者背 景と脳波異常についても簡単にふれておきたい。 Small $\left.{ }^{43}\right)$ は, 他の対照群と6c/s spike and wave を区別する唯一のものは, IPAT anxiety scale の高值であると言ったが、IQ，MMPIでは区別 できなかったと報告した．またOlsonら ${ }^{45}$ は，对 照群と $6 \mathrm{c} / \mathrm{s}$ spike and wave を示す群との比較 で, WAIS では明らかなものはなく, MMPIで はHy scaleが有意に高く, Bender-Gestalt test では, 脳機能の統合面の障害が示されたと報告 した。しかし彼は， $6 \mathrm{c} / \mathrm{s}$ spike and waveの最 終的な解釈は、なお詳細な研究が必要だとして いる. 今回著者は，一種の健康調查表である Cornell Medical Index (CMI) を用い て検討した。その結果, 神経症傾向の段階 と, DPHm賦活によるWSP 誘発例との間 の有意の相関は認められなかった。

次に，既往歴との関係で， $6 \mathrm{c} / \mathrm{s}$ spike and wave または狭義の WSP を示す例に頭部外傷の 既往を持つものが多いことを指摘するものがあ $3^{3,13,44)}$. しかし今回の検討では, 頭部外傷, 熱 性けいれん，精神神経疾患などの既往について も，DPHmによるWSP誘発例との相関は認め られなかった。

結局 DPHm によるWSP 誘発例と,なんら かの臨床的問題との間の有意の相関は見出すこ とはできなかったとしてよい，すなわち，健康 成人における DPHm 賦活によるWSP 出現頻 度は比較的高率であったが, それらの例に臨床 症状という観点からの問題を有するものはなか った．したがって，DPHm賦活で出現するWSP をもって，ただちに臨床症状との結びつきをう んぬんすることには慎重でなければならないと 言わさるをえない，さきに考察したように， 
DPHm 賦活陽性例になんらかの素因性基盤を認 めたとしても，これは脳波上のそれであって， 臨床症状との相関となると，なお間接的以上の 隔りを考えざるをえない。

4.同一人における DPHm賦活と Bg 賦活 の検討について

今回の結果, 絵括的に健康成人 470 名中 77 名 (16.4\%)に, DPHm 賦活により WSP が認め られた。また Bg 賦活では 119名中14名 (11.8 \%)に棘波を含む突発波が認められた。これは ある程度，類似する賦活率を示したと言える。 また同一人に行なった DPHm と Bgの両賦活法 の結果, 各賦活陽性者の半数前後に WSP また はatypical spike and wave complex が誘発さ れた。態代ら ${ }^{34)}$ は，てんかん群，頭痛群，頭部 外傷群，精神科疾患群などを対象に両賦活法を 行なった結果，てんかん群以外では， Bg の方 か，高率に賦活効果を示すのに比へ，てんかん 群では, 各々70\%以上の賦活効果を認め, 互い に同等の高い賦活率であったと報告した．さら に能代らは，同一人に行なった両賦活の検討で, 両者に对し同一波型を示すもの，異なった波型 を示すもの，この二者すなわち両賦活で重複効 果を認めるものが約半数（55\%）あったと報告 し, DPHmが Bgに劣らぬ有効な賦活法である ことを指摘している．今回は，对象が健康成人 ではあるが，両賦活法の各々が，ほほ同等の賦 活率を示すこと，また同一人における而賦活法 の結果, 粎半数が, 両者で重複賦活されたこと, これら二点は，DP H mがさきに考察した active activator としての性状を有するという推諭 を，間接的ではあるが，さらに支持する結果と 言之よう。

さて次に，两賦活によって示される波型につ いて検討したい。 つまり同一人において, DPH$\mathrm{m}, \mathrm{Bg}$ 両賦活法ともに陽性であった場合の波型 を検討したい. 今回規定し，すでに図 4 左に示 したような狭義のWSP 波型が，第 2，第 $3 の$ 研究すなわち同一人に对する DPHm, Bg 賦活 の両者を通し， DPHm 賦活陽性例全例に認めら れ，また Bg では，いわゆる atypical spike and wave complex も多く認められた。ここで詳細 に,これらの波型を検討すると，この賦活にお
ける atypical spike and wave complexは, DP$\mathrm{Hm}$ によって誘発されたWSP の棘波，あるい は徐波成分が堌強された波型としてみることも できる。すなわち WSP とatypical spike and wave complex とが, 波型の類似性において, 同一の基盤をもった “同種移行性”を示すもの ではないかと考えられる。この点に、これらが $6 \mathrm{c} / \mathrm{s}$ spike and wave として, これまで集約さ れてきた理由をみることができる．田中は299， 同一記録中にみられた $6 \mathrm{c} / \mathrm{s}$ spike and waveの 各種波型を図示しているが，低振幅の6 c/s spike and wave (㹟義のWSP) と, 一方また高振 幅の $6 \mathrm{c} / \mathrm{s}$ spike and wave が併存することから， これら 2 者を本質的に同じものとし，てんかん 発作間歇期に観察される atypical spike and wave complex とも同一のものとして考察して いる. Hughes 4), 最近, $6 \mathrm{c} / \mathrm{s}$ spike and wave に，1つは，より棘波成分の高いものと，1つ は，より棘波成分の低いものの 2 者があり，こ れら 2 者が併存する場合が多いことを示した。 前者は, 今回著者の言う atypical spike and wave complex, 後者はWSP である。そして，この 両者に連続性があることを推定している。

今回, 対象となったのは，すべて健康成人で あク，臨床例についての詳細な検討は他にゆず

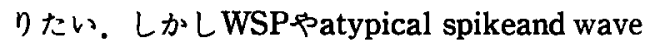
complex と臨床表出について，その関連性のみ に焦点をあてて検討してみよう。吉水ら ${ }^{46)}$ は， 精神疾患の Bg 賦活の検討で, 異常脳波賦活効 果か，对象者中の18才から30才において高く， その出現が, 中心脳性を予想されることから， 若年者の皮質下中枢の未熟性，またそれによる 機能的脆弱性をあげている. DPHm賦活で誘発 されるWSP についても，同様に間脳の機能障 害との関連を指摘するものがある14).しかし， 後者の場合も何らかの精神疾患群を対象とした ものである。一方 Mayo clinicの豊富な資料か ら，問題となるてんかんとの関連について。 Thomasら ${ }^{18)}$ は, WSP が直接てんかん者の示す 異常波とは言えない，少なくともWSP から， てんかんを推定することはできないと結論して いる. Hughesは4), $6 \mathrm{c} / \mathrm{s}$ spike and waveに 2 型を区別していることを先に述へたが，その棘 
波振幅の高いものが, より発作と相関し，棘波 振幅の低いものは,より自律神経定状や，精神 症状という評価の困難な症状に相関するのでは ないかと述べている。

そこで，次に今回の健康对象群における高率 のWSP の出現，種々の精神神経疾患における， 少なからざるWSP の出現これらの間の関連 をどのように思考すればよいかが，この研究の 目的であり，著者らの今後の追求の視点である とも言える. 究極的には次のように思考されよ う。すなわち，第 1 に指摘できることは，文献 的にみて，比較的年令依存性を有する波型であ ろうということである。したがって本研究の对 象者が，健康ではあるが，比較的若年層である ため，高率に賦活されたと考えてみることもで きる，次に文献的にも，阽床症状との相関が， 必ずしも説明しにくい以上，たとえ素因性基盤 を推定するにしても，これは，あくまでsubclinical electrical manifestation と考えざるをえ ない，そして発達過程における間脳下垂体系の 脆弱性の表現という臨床上の推論は, 今回の研 究からただちに否定したり，肯定したりという ことに慎重でなければならないであろう。さら にWSP という一脳波表現は，そのままclinical manifestationには至らない，良性の波型ではな いかと推論される. その他の点を含め, 今後検 討されるべき点であろう。

\section{ま と め}

1. 18 才から 40 才, 平均 $24.4 才, 787$ 名の健 康成人男子の脳波検查を施行し, 薬物賦活前の 脳波において,WSP の出現頻度は 8 名: $1.0 \%$ であった。

2. 全对象のうちから470名にDPHm賦活を 施行することができた． DPHm の用量は，0.5 $\mathrm{mg} / \mathrm{kg}, 1.0 \mathrm{mg} / \mathrm{kg}, 1.5 \mathrm{mg} / \mathrm{kg}, 2.0 \mathrm{mg} / \mathrm{kg}$ の 4段階に分けて投与された，その各々において WSP 賦活率は $15.4 \%, 20.8 \%, 12.2 \% ； 19.7 \%$ であった。

3 . したがってこの範囲の用量別においては， DPHm 賦活におけるWSP出現率に用量依存性 を認めなかった。

4. DPHm 賦活における, 全470名のWSP
出現率は平均16.4\%で，これは賦活前の出現頻 度 $(1.0 \%)$ に比べ有意の增加であった。

5.WSPと，なんらかの臨床表出との相関に ついて検討した．賦活前の脳波の基礎律動，そ の他の脳波所見，CMIにおける神経症傾向，既 往歴としての頭部外傷，熱性けいれん，精神神 経疾患などと WSP の間には有意の相関は認め られなかった。

6. DPHm 賦活陽性例に，Uきつづき $\mathrm{Bg}$ を， 一方 $\mathrm{Bg}$ 賦活陽性例に，ひきつづきDPHm を 同一人に行ない，相互の関連を検討した。まず $\mathrm{DPHm}$ は95名を対象とし $1.5 \mathrm{mg} / \mathrm{kg}$ を用い 14.7 $\%, \mathrm{Bg}$ は50mg を一律に119名に施行し， 11.8 \%に賦活効果を認め;ほほぼ類似の結果をえた。 次にDPHm賦活陽性例にBg賦活を行なった結果, 42.9\%に棘波を含む突発波を認めた。一方 $\mathrm{Bg}$ 賦活陽性例に DPHm 賦活を行ない $57.1 \%$ に. SPをみとめ，互いに類似した賦活率をえた。

7。而賦活により出現した波型の比較から， WSP, atypical spike and wave complexに同 種移行性を窥わせるものがあった。

8. 多数の健康成人における，以上のような 結果から, DPHm賦活によって出現するWSP をもって臨床診断を下すことには慎重であらね ばならぬことを指摘した。

9、WSP それ自体は，明らかな発作性波の形 態を持つが, いわば subclinical electrical manifestationであり，良性の波型であり，また年 令依存性を有するものではないかと考之た。

10. DPHmは，単に入眠期類似の脳波パター ンをもたらし，その状態下に 2 次的にWSP が 誘発されるとするよりも，より active activator としての性質があるのではないかと考え考察 した.

稿を終之るにあたり，終始，暖かい御指導と激励 をいただきました，細川清助教授に，深く感謝いた します。また本研究の実施には平田潤一郎，高橋幸 夫, 平田邦樹, 久鄉敏明各先生方の御協力と小野茂 美さんの助力があったことを感謝いたします。おわ クに，御校閱をいただいた大月三郎教授に深く感謝 
いたします。

なお本論文の要旨は第 4 回，第 5 回，第 6 回，第
8 回, 第 9 回の日本脳波筋電図学会並U゙に第10回国 際脳波，国際神経生理会議にて発表した。

\section{女献}

1. Walter, W.G.: Epilepsy. In Electroencephalography, ed. D. Hjll and C. Parr, MacMillan, New York, pp. 228-272, 1950.

2. Marshall, C.: Some clinical correlates of the the wave and spike phantom. Electroencephalogr. Clin. Neurophysiol. 7, 633-636, 1955.

3. Thomas, J.: A rare electroencephalographic pattern: the six per second spike and wave discharge. Neurology 7, 438-442, 1957.

4. Hughes, J.R.: Two forms of $6 / \mathrm{sec}$ spike and wave complex. Electroencephalogr. Clin. Neurophysiol. 48, 535-550, 1980 .

5.上平忠一： $6 \mathrm{cps}$ 棘徐波複合を有する内因性精神病の緥断的覾察．精神経誌．79，629-651，1977。

6. 堀映：Phantom spike and wave を示す症例の臨床脳波学的，精神医学的検討. 名市大医誌. 21，590$611,1971$.

7. 田中恒孝, 宮市俊一，小倉正己，莦藤正武：Phatom spike-waveについて. 臨床脳波。 12，423-428，1970.

8. Small, J.G., Sharpley, P. and Small, I.F.: Positive spikes, spike-wave phantoms and psychomotor varients. A survey of these EEG pattern in psychiatric patients. Arch. Gen. Psychiatry 18, 232-238, 1968.

9. 柳原正文，下田又季雄：非行少年における異常脳波について．臨床脳波，19，57-61，1977．

10. 大田原俊輔，石田俊二，岡 鍈二，大野 稔，伴鶴一，倉繁隆信，浜脇光範：微細脳障害症候群の脳波学 的研究一とくに行動異常の神経機序について一小児診療. 31，1233-1247，1968.

11. 大田原俊辅：小児行動異常と脳波。臨床脳波。13，10-23，1971.

12. 堀田正之，木佐彰三：小児の内臓発作（Visceral seizure）について。臨床脳波。9，17-28，1967.

13. Gibbs, F.A. and Gibbs, E.L.: Atlas of Electroencephlography. Addison-Wesley, Cambridge, Mass, Vol.3 pp. 46-47, 1964.

14. 下田又季雄：自律神経性てんかん一正しい概念規定を中心として一 神経進歩。12，677一694，1968.

15. 越野好文：正常人㸺波の再検討。精柛経誌。72，1051-1088，1970。

16. Tharp, B.R.: The six-per-second spike and wave complex. Arch. Neurol. 15, 533-537, 1966.

17. Hosokawa, K., Hirata, J., Kugoh, T. and Otsuki, S.: Induction of six $\mathrm{c} / \mathrm{s}$ spike and wave by diphenhydramine hydrochloride in healthy young males. Folia Psychiatr. Neurol. Jpn. 32, 231-235, 1978.

18. Thomas, J.E. and Klass, D.W.: Six per second spike-and-wave pattern in the electroencephalogram. Neurology 18, 587-593, 1968.

19. Silverman, D.: Phantom spike-wave and the fourteen and six per second positive spike pattern.: A consideration of their relationship. Electroencephalogr. Clin. Neuriphysiol. 23, 207-213, 1967.

20. Shimoda, Y., Yoshino, Y., Nanba, M. and Tanaka, K.: Variety of six and fourteen per second positive spikes and their clinical characteristics. Yonago Acta Med. 8, 59-68, 1964.

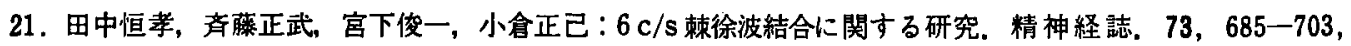
1971 .

22. 小泉 章：Diphenhydramineによる㸺波賦活法。米子医誌，10，55一67，1957.

23. Shimoda, Y., Koizumi, A. and Tanaka, K.: Electroencephalographic activation of "Diencephalic Epilepsy" with diphenhydramine. Yonago Acta Med. 4, 99-102, 1960. 
24. 平田潤一郎, 平田邦樹, 高橋幸夫：健康成人男子群の Diphenhydramine (DH) 賦活によるWSP 出現頻 度. 脳波と筋電図. 3, 111- $112,1975$.

25. 細川 清, 平田邦樹, 大月三郎, 平田潤一郎：健康成人男子群の Diphenhydramine (DHm) 賦活による Wave and spike phantom (WSP) の出現頻度 一続報一 脸波と筋電図. 4, 82, 1976.

26. 細川 清, 久郷敏明, 平田邦樹, 大月三郎, 平田潤一郎：健康成人男子群のDiphenhydramine (DH)賦活 による Wave and spike phantom (WSP) の出現頻度.（第 3 報）脳波と筋電図. 5, 14, 1977.

27 .細川 清, 久郷敏明, 高橋 茂, 大月三郎, 平田潤一郎：健康成人男子におけるDiphenhydramine hydrochloride $(\mathrm{DH})$ と Bemegride (Bg) 賦活の比較検討一WSP 陽性例に封する Bg 賦活, 脳波と筋電図. 7 , $57,1979$.

28. 細川 清, 高橋 茂, 久郷敏明，大月三郎：健康成人男子における Bemegride (Bg)と Diphenhydramine hydrochloride (DPHm) 賦活の比較検討 - WSPの性状に関する検討一. 脳波と筋電図. 8，26，1980.

29. 田中恒孝, 小合正己, 斉藤正武, 宮下俊一 $: 6 \mathrm{c} / \mathrm{s}$ 棘徐波複合の臨床脳波学的特徵について. 臨床精神医学. 2, 73-79, 1973.

30. 田中恒孝: Phantom spike and wave complex ないし 6/sec spike and wave complex ににいて. 精神医 学. 16, 4-18, 1974 .

31. 大熊殚雄：臨床眇波学. 医学書院, 東京. pp. 59-61, 1974.

32. Gibbs, F.A. and Gibbs, E.L.: Atlas of electroencephalography. Addison-Wesley, Cambridge, Mass, Vol. 3 p. 15, 1964.

33. 大田原俊輔、梶谷 喬, 志茂 実, 石田俊二, 片野隆司：小児臨床脳波におけるDiphenhydramine䟼活法 に関する研究. 日児誌，67，583一592，1963.

34. 熊代 永, 中村善信, 山田高春, 引地明義, 平田潤一郎, 伊丹仁郎：Diphenhydramineによる脸波賦活法 一特に Megimide 賦活法との比較一，臨床脳波。12，263-270，1979。

35. Diaz-Guerrero, R., Feinstein, R. and Gottlieb, J.S.: EEG findings followings intravenous injection of diphenhydramine hydrochloride. Electroencephlogr. Clin. Neurphysiol. 8, 299-306, 1956.

36. Churchill, J.A. and Gammon, G.D.: The effect of antihistaminic drugs on convulsive seizures. J. Am. Med. Assoc. (J.A.M.A.) 141, 18-21, 1949.

37. Wyngaarden, J.D. and Seevers, M.H.: The toxic effects of antihistaminic drugs. J. Am. Med. Assoc. (J.A.M.A.) 145, 277-283, 1951.

38. 鬼塚利雄：Diphenhydramine の中枢作用。米子医誌。9，1002-1012，1958.

39. 尾崎端爾：Diphenhydramine の中枢作用補遺. 米子医誌。18，436-449，1967.

40. 島本暉朗：抗ヒスタミン薬：薬理学. 島本暉朗, 山本 繁, 森田雅夫, 高木博司共著, 医学書院, 東京, pp. $475-479,1964$.

41. 大田原俊輔：小児脳波倵活法一小児てんかんを中心として一医床脳波８，13一25，1966.

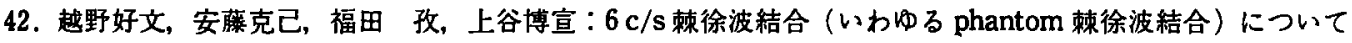
の一考察. 臨床脳波, 12, 375一 $379,1970$.

43. Small, J.G.: The six per second spike and wave-A psychiatric population study. Electroencephalogr. Clin. Neurophysiol. 24, 561-568, 1968.

44. Hughes, J.R., Schlagenhauff, R.E. and Magoss, M.: Electroclinical correlation in the six per second spike and wave complex. Electroencephalogr. Clin. Neurophysiol. 18, 71-77. 1965.

45. Olson, S.F., Arbit, J. and Hughes, J.R.: Psychological testing in patient with the $6 \mathrm{c} / \mathrm{sec}$ spike-andwave complex. A controlled study. Clin. EEG. 2, 202-205, 1971.

46. 吉水俊一, 山内 均, 高井作之助, 工藤 勉, 服部隆夫, 白木弥三一：精神疾患の Bemegride賦活. 名市 大医誌. 19, 1727-1732, 1969. 
Induction of $6 \mathrm{c} / \mathrm{s}$ spike and wave by diphenhydramine

hydrochloride in healthy young males.

(Special reference to wave and spike phantom)

\section{Shigeru TAKAHASHI}

Department of Neuropsychiatry, Okayama University Medical School.

(Director: Prof. S. Otsuki)

The incidence of $6 \mathrm{c} / \mathrm{s}$ spike and wave or wave and spike phantom (WSP) was examined by administration of diphenhydramine hydrochloride (DPHm). And the nature of $6 \mathrm{c} / \mathrm{s}$ spike and wave or WSP was studied.

1. There were 787 subjects, all of whom were healthy young males with a mean age of 24.4 years. The incidence of WSP in these subjects before administration of DPHm was 1.0\%. Of these, $\mathbf{4 7 0}$ subjects were given DPHm. The incidence of WSP after DPHm administration was $16.4 \%$. WSP incidence after DPHm administration was much higher than that of routine EEG recordings.

2. Dosage of $\mathrm{DPHm}$ were $0.5 \mathrm{mg} / \mathrm{kg}(\mathrm{N}=52), 1.0 \mathrm{mg} / \mathrm{kg}(\mathrm{N}=72), 1.5 \mathrm{mg} / \mathrm{kg}(\mathrm{N}=189)$, $2.0 \mathrm{mg} / \mathrm{kg}(\mathrm{N}=157)$. The incidence of WSP did not vary with the dosage.

3. Comparisons were made between the WSP positive and negative subjects in past histories, Cornell Medical Index results and in the basic activity of each EEG recordings. No significant differences were observed in these parameters.

4. Ninety-five subjects were injected first with DPHm $1.5 \mathrm{mg} / \mathrm{kg}$. Bemegride (Bg) was administered to the subjects showing WSP after DPHm injection. One hundred nineteen other subjects were injected first with Bg 50 mg. Subjects showing paroxysmal discharges with spike components after $\mathrm{Bg}$ were given $\mathrm{DPHm} 1.5 \mathrm{mg} / \mathrm{kg}$. The incidence af ter Bg and the incidence after DPHm were closely resembled each other.

5. These wave forms provoked by both $\mathrm{DPHm}$ and Bg administration were compared in the same individual. DPHm induced almost exclusively WSP form. Bg mainly showed atypical spike and wave form. Thus the author speculated that the WSP and the atypical spike and wave are the continuum.

6. Carefull attention should be given to the clinical diagnosis in cases where WSP has been demonstrated only by DPHm.

7. WSP after DPHm administration should be considered as a subclinical electrical manifestation. The incidence was very different according to age.

8. This study showed the possibility of DPHm having the property of the active activator. 